\title{
Chapter 5 \\ Applied Political Theory and Qualitative Research in Migration Studies
}

\author{
Ricard Zapata-Barrero
}

The decision to interpret or not to interpret is not an option open to human beings (Ball 1995: 7)

If there were only one truth, you couldn't paint a hundred canvases on the same theme (Picasso 1966)

\subsection{Introduction: The Benefits of Bridging Political Theory and Qualitative Research}

This chapter proposes a framework for a dialogue between theoretical normative issues and empirical research in migration studies. My point of departure is that political theorists and qualitative researchers are likely to be working in different academic rooms, but within the same social science building. Apparently, they have no relationship. Roughly speaking, political theorists evaluate the application of normative liberal-democratic principles (such as the freedom of movement, the equality principle, non-discrimination, the freedom of expression, etc.) and values (justice, good governance, solidarity, humanitarianism, security, well-being), and qualitative researchers are concerned with how subjective views determine perceptions and behaviour. However, I argue that they probably have access to the same

\footnotetext{
To my Master's students, especially those attending the course on Foundations of Immigration Policies. This chapter benefitted from comments on earlier drafts from Gritim-UPF researchers Evren Yalaz, Nuria Franco, Mohamed El-Bachouti and Luisa Faustini. Special thanks also go to students of the 8th edition (2016-2017) of the Master on Migration Studies at UPF, who gave me helpful comments at final drafts: Vittoria Emanuela Bria, Carmen Ruiz Itzel and Laura Alzola.

R. Zapata-Barrero $(\bowtie)$

Political and Social Sciences Department, University of Pompeu Fabra - GRITIM-UPF,

Barcelona-Catalonia, Spain

e-mail: ricard.zapata@upf.edu
}

R. Zapata-Barrero, E. Yalaz (eds.), Qualitative Research in European Migration

Studies, IMISCOE Research Series,

https://doi.org/10.1007/978-3-319-76861-8_5 
viewpoint, especially when they try to interpret migration and diversity dynamics. Unfortunately, their links have thus far been unexplored. I will first highlight how Political Theory (PT) and Qualitative Research (QR) both have common features in how they focus their work, how they relate to their object of study and how they produce knowledge. The evaluative character following conceptual and normative analyses is what is distinctive to PT (Pettit 1991), and the identification of themes and patterns of particular migration issues is what is peculiar to QR (Miles and Huberman 1994; Ritchie and Lewis 2003). This chapter not only underlines that there are many commonalities between them, but also concentrates on the benefits they can generate: QR provides PT with evidence-based and knowledge-based patterns, and PT provides QR with theoretically founded normative arguments. We know that PT contains many empirical assumptions and QR contains many assumed normative ideas, so the bridging benefits are complementary. In working together, they can each produce more pragmatic knowledge linking the "is" (realism) and the "ought to be" (idealism) (Carens 1996) of most arguments related to migration governance and diversity management, and develop an empirically informed critical thinking to migration studies. I am not intending to signal that qualitative researchers do not theorize or that political theorists do not engage in "real-world" issues, but rather that each area of research can benefit from the other to better perform their own tasks.

Among the variety of theoretical frameworks in QR (Anfara and Mertz 2015), I will focus on the qualitative content analysis. Broadly speaking, this means the systematic classification of the process of coding which can help identify themes or patterns through the interpretation of the content of text data (Hsieh and Shannon 2005: 1278). Concerning PT, I will follow Applied Political Theory (APT). This particular field can be considered as the evidence-based dimension of PT (ZapataBarrero 2004). APT is always concerned with practical viability, reliability and feasibility of normative ideas. Its main concern is not only to learn more about how to apply principles and values (for instance, the equality principle, the nondiscrimination principle, solidarity and security, etc.) in a given context (Baubock 2008), such as in the workplace, in schools, or at the admission level of borders, but also to question why most of the time these principles have difficulties in guiding given practices. APT's main focus is on principles guiding particular cases (Favell 1998). In our understanding, a principle is a way to relate means and goals of a given position in order to manage an issue. It is normative when, for instance, it includes deontic operators (related to duties, permissions, and related concepts), such as ought, may, permissible, obligatory, right, or wrong, as is mostly the case in theoretical political thinking on diversity and migration issues.

From APT, we can say that there are instrumental and deontological principles. The first one emphasizes more on the importance of the means to achieve a goal; whereas the goal is of primary concern for the second one, whatever the means. In analysing migration-related conflicts, there may be actors providing solutions to the situation following deontological and instrumental principles. The respect of human rights, for instance, can be a deontological principle defended by NGOs and social movements in evaluating how state institutions control flows; and the fact that 
international rules must be respected in dealing with refugees, even if they infringe basic human rights. This can be considered an instrumental principle within the same refugee's situation.

Most political theorists recognize that what distinguishes them from other social science fields is that they combine conceptual, normative and evaluative analyses (List and Valentini 2016). APT seeks to evaluate patterns within a given normative framework (justice, goodness, equality, freedom, solidarity, etc.) (Zapata-Barrero 2004). In other words, it tries to determine the good or the bad, the better or the worse, the desirable or the undesirable in analyzing conflicts and in identifying migration-related paradoxes (Cole 2000; Spencer 2003). Laegaard (2016) says that normative political theory formulates evaluative claims about the legitimacy, justice, or relative goodness of acts, policies, or institutions; and prescriptive claims about what we should do, which decision procedures we should follow, or how institutions should be reformed. In migration studies, this means, for instance, the questioning of the legitimacy of control policies, on the lack of opportunities for social mobility for migrants, how the structure of society determines migrants' life expectations, xenophobic political discourses, and religious diversity management contradictions (how to accommodate religious diversity in secular and democratic societies, for instance, Bader 2007).

A research focus that centers on deficits using the "gap hypothesis" is also wellknown in migration studies, as is the so-called "policy gap" between migration policies and their outcomes (Guiraudon and Lahav 2007). In fact, migration studies develop most of their research frameworks by identifying the existing gaps between current dynamics and old structures and policy paradigms. The identification of democratic deficits and policy contradictions in diverse societies also belong, in my view, to the premises of APT, and most of the time it is presented in terms of fracture and contextual restraints that force these contradictions, especially national-based policies (Cole 2000).

There is also a "diversity gap" in public institutions, which means, in broad terms, the distance between social-diversity dynamics and the participation and representativeness of schools, police, public administrations, political parties (ZapataBarrero et al. 2017b), trade unions (Penninx and Roosblad 2000), and parliaments (Bloemraad and Schönwälder 2013). Most of the works on political participation and representation probably fall within this focus. How diversity, for instance, becomes a factor in understanding social inequalities, power relations and distrust, has centered mostly on the literature working within the inclusion/exclusion, democratic/undemocratic divide framework (see, for instance, Martiniello 2005; Hochschild and Mollenkopf 2009; Bird et al. 2011).

APT generates arguments by contrasting principles and their application to present-day problems (Smits 2009; Favell and Modood 2003). And by doing so, the normative evaluation becomes critical for current practices, since it develops the resources that are needed to identify contradictions and paradoxes (White 2002: 474). For instance, in a ground-breaking work Carens (1987) identified a contradiction in liberal states: if we accept that freedom of movement is a core liberal principle, then the liberal tradition cannot accept the closure of borders. There was no way for Carens to justify the control of borders given such established liberal principles. 
Similarly, with the paradox formulated by Hollifield (1992), who explained that, while there are some principles involved in sustaining some institutions that legitimize restrictive policies (national and welfare states), others produce claims for admission (market). It is then through APT that we can identify the contradictions of societies and political institutions when managing migration processes. Such paradoxes exist between security and freedom/equality, human rights and security in areas such as border policies debates, and solidarity and interest, to mention some key discussions. These conceptual frameworks are not only present at the border and at human mobility levels, but also at the incorporation and diversity accommodation levels. The different citizenship regimes, for instance, give political rights according to subjective national-interest criteria (Slim and Squires 2008). There are certain paradoxes that exist which are related to how to manage inequality of opportunities between immigrant workers and citizen workers, and the contradictions between socialization processes of young migrants and their opportunities for social mobility (Crul and Vermeulen 2003; Crul et al. 2012). What all these situations have in common is the contrast between principles and values (equality, freedom, respect, tolerance, solidarity, etc.) and their application or the fact that not all principles and values defended by each position can be applied at the same time (incommensurability).

APT places these conflicts under the umbrella of some theoretical frameworks. In migration studies, the links between unity and diversity, inclusion and exclusion, majority and minorities produce substantial debates (Boccagni 2015; Meer et al. 2016; Triandafyllidou and Gropas 2015). The recent work of Hampshire (2013) probably illustrates this view. The book shows how four defining facets of the liberal state - representative democracy, constitutionalism, capitalism, and nationhood - generate conflicting imperatives for immigration policymaking, which in turn gives rise to paradoxical, even contradictory, policies.

To underline the benefits in linking APT and QR, I propose to follow a conflictbased approach, since I argue that it is through conflict analysis that we can unravel their potential. Subsequently, after a section presenting the specificities of conflict and how to focus a conflict-based approach, I will devote the remainder of the chapter to the three main bonding practices of the understanding function: interpreting, conceptualizing and contextualizing. The logic of research can be summarized as follows: (1) choose a problem; (2) identify the main actors as key players of the conflict; (3) identify their shared guiding-question (4) analyse their position regarding a problem through the search for arguments (answers) of the guiding question.

I propose to apply this conflict-based analysis at the meso-level (level of collective action and network relations), without neglecting the macro-level (level of public structures and state institutions) where I will frame the context. As there are a great variety of possibilities within the meso-level, I will take into account different actors working on migration issues from particular administrations, international organisations, NGOs, immigrant associations, civil society organisations, trade unions, political parties, etc. I will end the chapter with a special claim that what probably makes these bridging and bonding elements between APT and QR stronger are that they produce critical knowledge that is not only social and political, but also theoretically founded and empirically grounded. 


\title{
5.2 Bridging Elements: What a Conflict Is and How to Focus a Conflict-Based Approach
}

The best starting point to engage with the definition of a conflict can be found in a ground-breaking essay of Simmel, when he correctly asserted:

\begin{abstract}
That conflict has sociological significance, inasmuch as it either produces or modifies communities of interest, unifications, organizations, is in principle never contested. On the other hand, it must appear paradoxical to the ordinary mode of thinking to ask whether conflict itself, without reference to its consequences or its accompaniments, is not a form of socialization. (Simmel 1903: 490)
\end{abstract}

The premise is then to consider a conflict as a factor of socialization and an indicator of social change. In broad terms, a conflict can take the form of racism in the competition for scarce resources between immigrants and citizens, between immigrants themselves and immigrant and state institutions, and then, instead of, social and economic equality, prejudices and inter-group relations can take the form of power relations, limits in participation and under-representation. A "conflict zone" can also have cultural and economic dimensions (even structural and legal dimensions) as well as different categories that are diversity-based, which can help to frame a problem: for example, religion, language, age and gender. Most conflicts related to religious pluralism, to national identity or to social rights are probably distinctive to the European approach. This may be due to the particularity of European welfare systems and European nation-building processes, or even to the history of how Europe has managed religious tensions in the past and/or the colonial past of most of its States. I can even say that what drives a category is always its conflictive dimension. Otherwise it would become meaningless (Vertovec 2015; Jehn et al. 2008), because one of the most important functions of a category in migration research is to make tensions visible. What interest us is a shared view about what a conflict is and to develop what bonds APT and QR: the view that a conflict always involves a set of key-agents, each defending their own interpretation and interest of a given fact, policy or declaration. The starting point is to frame the plurality of existing positions that surrounds a migration-related problem.

There is already a large body of literature on immigration and conflicts, which is primarily related to social movements and ethnic relations (Dancygier 2010) and now with crime and terrorism (Freilich and Guerette 2006). A common core of all typologies is the fact that it involves different agents. A conflict can arise due to a social dynamic ("boat people" in the Mediterranean or neighbourhood protests against the building of a Muslim oratory or mosque), a contested policy (prohibition of burkinis - the full-body swimwear that Muslim women wear at public beaches -, which provoked a national identity debate in France after an incident in Nice in the summer of 2016), or a reaction to a discourse (the declaration of Chancellor Merkel that multiculturalism is dead in October 2010, for instance, or the key discourse of former British Prime Minister D. Cameron on 5 February 2011 on radicalization and Islamic extremism). A conflict expresses not only disagreement between the parties, but a perception that the "other" views are a threat to the accomplishment of 
one's own view. The nature of most migration-related conflicts takes the form of this disjunction. For instance, if you follow a humanitarian-based approach to refugees, the security-based approach followed by most states can be perceived as a threat. There is always a certain degree of incompatible views around a conflict, which can exacerbate the tense situations when all the parties try to impose their interpretation to the detriment of the other. This is the starting premise of radical views and critical positions. And in migration dynamics and governance, many conflicts can take this shape. It is precisely what I may call these "conflict zones" that are more productive in terms of the generation of different visions. Following mainstream conflict theories (Oberschall 1978, 2010; Gibney 2008), the fact that a disagreement implies a threat gives rise to a competitive situation around the different means/goals to solve an emerging problem. Consequently, a conflict always describes the fact that there are different positions on how to solve a given problem, and not all can be applied at the same time in their complete form. There will always be "winners" and "losers" in terms of their own narrative. One challenge when following a conflict-based approach in migration research is to determine the different forms a conflict can take (identity, race, socio-economic, legal conflicts).

The incommensurability of values and principles is consubstantial to PT (Hsieh 2016) and it implies that conflicts cannot be reduced to a common theoretical standard or measure. Of course, there can even be different interpretations around the problem-formation, and a conflict may even arise because all the parties do not always share the same definition of a migration-related problem. For instance, in diversity research, some may problematize the under-representation of migrants or citizens with immigrant background in parliaments, in political parties, or in public administrations in general, while others would not categorize this evidence as problematic (Zapata-Barrero et al. 2017b). The conflictive scenario can be political or social in its origin and aftermath. From an APT's perspective, the differences are related to social/political means/goals to reach a problem-solution. Social cohesion and political stability are the usual bases to standardize normative evaluation. Of course, a conflict situation in migration studies can also have more virtual realities than "real realities", in the sense that the parties defending their own positions (means/goals) defend "their truth", even if it is constructed through a set of misinterpretations (the fear of invasion of migrants to justify their own position against a flexible border policy, this may be unfounded, but true as a fear). There can also be a set of contextual factors influencing the position of the parties. For instance, factors related to positions of power and the legitimacy within the system, as well as evidences linking the actor with the topic and the influence it can have on its process. These contextual factors situating the parties in terms of power and structure of opportunities are important to highlight since they can perfectly influence the conflict analysis. The argument here is that not all parties have similar power/ strength to advocate for their own position and implement their goals. In this sense, a conflict always reflects the power relations existing in the society. This is common in the study of public opinion, of public policy processes, or even in critical dis- 
course analysis, when political parties sometimes resolve virtual problems, such as the link between Syrian refugees and terrorist attacks, to gain attention. We know likewise that Islamophobia is generally a political construction, rather than a social reality (Zapata-Barrero and Díez-Nicolas 2012). For APT and QR, the purpose is not to evaluate the "truth" of a position, but to analyse the fact that there is a real conflict of positions (different views on the means and goals to solve a problem).

In this preliminary process of conflict-definition, the political theorist must try to identify the main normative arguments and existing principles involved in the topic under discussion, and link them to the interpretations produced by the different actors previously identified. One good illustration of this analysis is the Special Issue on the 'Muhammad Cartoons' case in September 2005, in Ethnicities (Lindkilde et al. 2009), where the principles of freedom and equality were mobilized by different actors, reflecting a multicultural crisis in Europe (national controversies over religious diversity). Several works related to multiculturalism and European identity are now penetrating the European migration debate (Triandafyllidou and Gropas 2015; Kastoryano 2009) along similar lines.

The premises of a conflict-based approach are that arguments and debates produced by different actors are central to the process of conflict formation. Therefore, the main purpose would be to saturate all the potential existing positions that there are around a problem. This saturation technique is one distinctive feature of sampling in qualitative research (Bowen 2008) and it is used by researchers not only as an indicator of quality (Guest 2006), but also as a technique that hampers content validity (Fusch and Ness 2015). This is done not from abstract suppositions, but rather from concrete actors' perceptions. Interpretation formation will then be done primarily using qualitative techniques (discourse analysis, interviews, observations, focus-groups, etc. See other chapters in this volume) to generate information basically coming from the agents involved in the conflict. This is why the identification of a conflict needs to be in tandem with fixing conflict-related agents. Each actor is an interpretation-producer, and the identification of the web of interpretations through qualitative techniques is one of the first channels an APT has to develop for its normative evaluative purposes.

\subsection{Bonding Practices of the Understanding Function Between APT and QR}

The basic argument in this section can be stated as follows: to understand a conflict is to assume that behind a conflict there is always a web of interpretations, a web of concepts, and a web of particular contextual circumstances, which need to be inferred through the use of qualitative techniques. When delimiting a case, we start from a conflict, and then select a process (for our purposes, this is the basic operation of contextualising) that will allow us to frame a web of interpretations and 


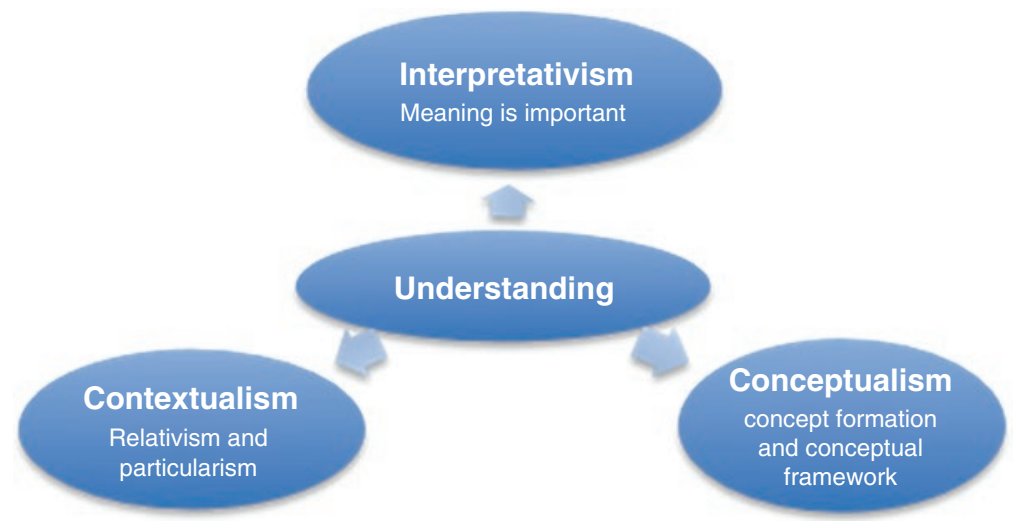

Fig. 5.1 Bonding practices of the understanding functions between APT and QR

finally define the main concepts that arise from these interpretations. Thus, there are three basic operations in the practice of understanding a conflict: interpretation, conceptualisation and contextualisation.

Graphically speaking (Fig. 5.1):

\subsubsection{Interpreting: The Importance of the Meaning}

"To interpret" means, literally, "to give meaning". It is futile to ask if you are for or against the use of interpretation in the field of migration research. There is no choice indeed. Paraphrasing Ball's words, "the decision to interpret or not to interpret is not an option open to human beings" (Ball 1995: 7). In fact, what bonds APT and QR is the hermeneutic method of "interpreting interpretations". As I place the analysis at the meso-level, the first purpose is to identify the interpretations given by actors or institutions involved in the conflict, and once saturated, to identify frames and themes that will inform patterns (QR), and analyse them through a normative evaluation (APT). For both, interpreting has, first of all, a cognitive significance, in the sense of accounting for how actors attribute meaning to a problem-solving situation. Interpretative research then designates those approaches that position meaning as a fundamental element of social (inter-) action (Schwartz-Shea and Yanow 2012). This is the basis of the interpretative turn, which is at the forefront of positivist methodology and is based more on facts than on meanings (Yanow and SchwartzShea 2006: Xi-Xiii). It also represents an ideational turn in QR directly linked to PT, since it also claims that ideas, values and principles influence perceptions and actions, independently of whether they are true or not, and respond to prejudices or prejudgments.

Accordingly, "interpretivists assume that access to reality (given or socially constructed) can only be done through social constructions such as language, con- 
sciousness, shared meanings, and instruments" (Myers 2008: 38). Therefore, the way actors and institutions "give meaning" to problems is important to analyse in order "to give meaning to the meanings". This second-order level function is then paramount. It combines ontological (how to identify a given problem) and epistemological questions (how can we know this is a conflict-related problem). An interpretative methodology holds that there is no direct, unmediated access to reality (a basic claim in interpretive epistemology), and this, in turn, means that humans interactions with their external worlds are always already mediated by the cultural contexts in which they find themselves (Yanow and Schwartz-Shea 2009: 34). To interpret how an actor interprets a given conflict is, therefore, a task that allows us to link QR and APT, since it also looks to identify what is distinctive between different views, not what is general and representative. In fact, what actors share and what they do not share within a given conflict is probably the primary dividing line that an interpretivist researcher must draw.

But if an interpretation is the whole recipe, what are the ingredients? Certainly, as we are in a conflict-based scenario, the process of interpreting allows us to differentiate perceptions and approaches to the conflict. This also posits that every interpretation responds to a given interest; it is not value-free. As we are working mainly at the meso-level, an interpretation can contain different actor's interests and viewpoints. An interpretation can not only include a diagnosis of a given situation, but also explanations and ways to solve the problem. Sometimes, of course, actors are not coherent among these three narrative levels (diagnosis, explanation and solutions), and the viability/feasibility nexus can also become a matter of conflict among actors. For instance, in the current refugee crisis, there are not only actors welcoming refugees for humanitarian reasons, but also other agents who are more oriented towards the feasibility and security consequences of welcoming people without limits. As Sigona (2014) advises, there are many crisis in the refugee crisis. The purpose is not to evaluate interpretations, but to understand conflict through the identification of interpretations. What we wish to develop, therefore, is how do we analyse an interpretation.

Generally speaking, actors formulate arguments around a conflict. These arguments describe the conflict, explain it and prescribe some solutions. These three narrative levels (description, explanation and prescription) can be coherent and interrelated, but not necessarily so. Through interviews, we can formulate questions related to each level of argument. Through content analysis of a party manifesto or a social report, we can also differentiate these narrative levels. Of course, these different ways of describing/explaining/prescribing could be coded and these different categories could be grouped according to different actors. The categories must be coherent among them, and can take different forms: in terms of diversity-related arguments (identity, economic, social arguments) or in terms of the given conflict (humanitarian and security arguments around the refugee crisis, for instance), as well as related to principles and values (equality, freedom, respect, solidarity, common humanity, opportunities). Likewise, the fact that some actors hold specific interpretations is dependent, of course, on their place in the political process. In general, NGOs and immigrant associations tend to have a more humanitarian view 
and deontological arguments of given conflicts, up to the point that they can be at the origin of processes of change in migration dynamics. Political parties and administrations tend to have a much more security and instrumental logic of thought when describing/explaining and prescribing solutions to a conflict. However, this is not always the case. Taking a multilevel analysis, cities and states have not always had the same narrative towards the same problem, as is the case today with the refugee crisis (Glorius and Doomernik 2016). This local turn, or the fact that cities can be active agents producing different narratives, is a path of analysis in multilevel migration studies (Zapata-Barrero et al. 2017a). These are, of course, tendencies. We know perfectly well that the power relation could explain determinate positions, as well as governmental responsibilities and inter-dependencies among actors. But this hypothesis-building reflection probably goes beyond the scope of this preliminary chapter.

\subsubsection{Conceptualizing: Concept Formation and Conceptual Framework}

The process of building a conceptual framework is consubstantial to the process of understanding. But concepts are not cut in stone and are never neutral, they respond to different meanings and purposes. Social and political controversies around a phenomenon always take the shape of a web of concepts. This is why the identification of key-concepts in a conflict is paramount. In fact, the major disputes among actors revolve around the meanings of key-concepts. For instance, Portes (2008) analyses the concept of social change related to migration studies; Kymlicka (2015) has recently offered some reflections on the concept of solidarity in diverse societies, or my recent proposal on the concept/policy framework of analysis for the emerging debate on interculturalism (Zapata-Barrero 2015).

Weber notes that progress in social science occurs through conflicts over terms and definitions (quoted by Gerring 1999: 359). The fact is that disputes about concepts often reflect deeply opposing approaches around a conflict. A long-standing concern in PT is the analysis of political concepts: freedom, equality, justice, authority, legitimacy, democracy, welfare, and so on. Each of these has been defined in numerous ways, following different democratic traditions, and PT can help us clarify the background of different interpretations. For APT, each concept has a domain of application. That is, a set of objects of which it is meaningful to ask whether they fall under the given concept or not. We might say, for example, that the domain of the concept border control is a network of actors and institutions doing/deciding border control, and even criticising how this control is done in practice.

A conceptual framework can be then defined as a network of interlinked concepts that together provide a comprehensive understanding of a phenomenon. This is not merely a collection of concepts, but, rather, a construct in which each concept plays an integral role. According to Miles and Huberman (1994: 440), a conceptual frame- 
work "lays out the key factors, constructs, or variables, and presumes relationships among them". In research terms, a conceptual framework is not composed of variables or factors, but of categories within a web of concepts that maintain meaningful relationships among them. The purpose is not to provide a causal/analytical setting, but, rather, a framework to understand a given migration-related conflict. Conceptual frameworks are indeterminist in nature and, therefore, do not enable us to predict an outcome, or even to explain it. Rather than offering explanation, as do quantitative models, conceptual frameworks provide understanding. A conceptual framework does not provide knowledge of "hard facts", but, rather, a "soft interpretation of intentions" (Jabareen 2009). The construction of a conceptual framework can be a product of these interlinks between APT and QR, and a conceptual analysis may offer normative guidance (Margolis and Laurence, 2014). This focus certainly has a long tradition in PT. In seminal work, Weldom (1953) noted that most of the discussion in PT does not have a factual content, but instead deals with arguments and definitions, namely that most conflicts are nominalists. Concepts such as 'power', 'justice', 'freedom', 'humanity', 'solidarity', 'security', are "essentially contested", in the sense that there is no neutral definition, but are rather always a matter of interpretation. The different ways actors use the same concept gives rise to different conceptions. The analysis trying to infer the concept and the conceptions can help us understand how actors give meanings to their positions in a given conflict.

Following the literature on the "essentially contested concepts", there is a conceptual core or a nuclear definition, which is shared by all actors using the concept in a given conflict. Most of the migration-related concepts mix description (what is the concrete reference of a concept) with normative dimensions (behind a concept, there is always some principles and values orienting action and regulating behaviour). Likewise, behind concepts, there are not only principles and values, but also practices. The concept of "humanitarian help" or even the concept of "welcoming policy" has its meaning only through given practices.

In the analysis of a given conflict, once we have identified the main actors involved (and for us, providing different interpretations around the conflict), the inference of the key-concepts framing the conflict can help us articulate different arguments according to given guiding-questions. The conceptual map must always be constructed as being the answer of a key question. Concretely, it is a way to conceptually organize the answer through arguments. This is why the identification of the guiding-question is so paramount in the process of understanding a conflict. As Saunders et al. (2015: 3) state,

Using the analogy of a box for the mental image or abstraction, a concept is the box in which we place things we believe to have aspects in common. The concept of organisation therefore includes a wide range of elements, such as people, structure, roles and responsibilities, learning and so on.

To draw a conceptual map of the conflict means to answer the questions: (a) what are the basic arguments and how they relate to each other so that we may understand them in conflictive terms?; (b) what are the different guiding-questions assumed or explicitly posed by the different actors around the conflict?; (c) how are the different 
interpretations of the conflict organized: around which guiding-question? Of course, a conceptual framework needs to be validated, that is, once constructed it must also make sense to other researchers, and we must be able to answer the question: does the framework present a reasonable understanding for scholars studying the phenomenon? Finally, the overall purpose of developing a conceptual framework is to make research findings meaningful and generalizable.

But most concept theorists also share the idea that the purpose is always to place concepts in context, since it is the context that certainly helps to identify meanings. Conceptual analysis is a highly contextual process (Gerring 1999: 366. See also the contribution of R. King, Chap. 3 in this volume).

\subsubsection{Contextualizing: Against Scepticism and Universalism}

Frege famously declared in section 60 of his The Foundations of Arithmetic (1884) that only within complete sentences do words have meaning. This different principle of compositionality is usually referred to as the context principle. Contextualism is seen as a part of the methodology to understand interpretations, and in our case, migration-related conflicts. It has been a common concern both for APT and QR. It is consubstantial to qualitative research on migration, and the framing of political theories on diversity of cultures, since most of the arguments come from the inference on particular cases. Both share the view that behind a conflict there is a web of particular contextual circumstances, which need to be identified. As a determinant of understanding, to contextualize a conflict is to place the conflict within a process.

This contextual approach has been explicitly discussed by political theorists dealing with diversity, from the seminal claim of Carens (2004) to Bader and Saharso (2004). A similar approach can also be found in the work of Kukathas, who affirmed that "much of the political theory of multiculturalism seems to be of the contextual variety" (2004: 215), and to the most recent works of Lægaard (2014, 2016). We can also include qualitative researchers mainly introduced by cultural studies (Schwandt 2007: 43), when it is said that "interpretations are context bound in the sense that a specific situation determines the form and direction of an interpretation". Contextualism, in Miller's sense, is the position that principles of justice are not universal, but context specific (Miller 2013: 42-43). Knowledge/understanding and context have, therefore, a necessary epistemological implication. Context denotes a description of particular cases, specific facts or their particular circumstances. From an epistemological point of view, the importance of contextualism and its role in contributing to providing meaning to interpretations is also an argument both against scepticism and against universalism (Cohen 1986; De Rose 1999; Rysiew 2016), and against overgeneralizations in most political theory arguments arising from one context and translated to others (Lægaard 2016: 262).

To contextualize a conflict is to place the conflict in a specific phase of a continuum line process with other phenomena. The process of conflict-identification cannot be done without a rigorous contextual framing technique. "Framing" means, 
first of all, to place the conflict within a given topic, and in a specific time and place. For instance, in the process of migrants' incorporation in a school, some conflicts may arise in the process of solving the problem of the concentration of migrants in a determinate school (place-frame) and moment (time-frame), or the wearing of chador by some girls in a specific school. The determination of the topic, the place and the time will indeed constitute the contextual focus of the conflict. Once the conflict has been focused, the qualitative researcher can leave "place" to the political theorist. This is why there can be two kinds of sources that APT can use to analyse interpretations and frame the conflict. Primary sources directly related to the specific context where the conflict arises (information directly produced during the conflictive situation by the main agents involved, such as public administrations, political parties, immigrant associations, trade unions, neighbourhood associations, NGOs, etc.), and secondary sources directly related to the identified topic, (for instance, the debate on religion/concentration of immigrants and the school in our example). In the previous case, large scholarly literature exists on migration studies linking diversity, religion and schooling (for example, Triandafyllidou et al. 2012). For instance, in this context, the principle of equality of access to school is at odds with the secular principle of national identity. The same conflict can then be solved according to different standards. In Catalonia, the right to go to school has priority over whatever religious considerations there may be (Generalitat de Catalunya 2015). The Islamic scarf controversy in France, however, follows another route, favouring secularism over the right to school (Arslan 2015). Or we can also take other examples where the core debate is not only about the different principles followed to solve a problem, but the ranking of them.

If context plays an important role in PT, there will always be an issue of delimiting it, since it then seems crucial to invoke what are the "relevant facts". In her most recent overview, Lægaard (2016), for instance, distinguishes different dimensions of contextualism. The "issue contextualism" refers to the process of setting out specific cases in relation to theoretical arguments, and "methodological contextualism" also means that context can be relevant to formulate/test and modify given theories. In this case, some critical scholars doubt that it can be a distinctive dimension of political theory (Kukathas 2004). As Levy (2007) notes, this methodological contextualism is very close to the "reflective equilibrium" (Rawls 1999: 18-19, 42-45), so clearly shared by Carens (2013), when he stressed that the way we compared general principles with particular cases in order to see whether the implications of the principles square with considered judgments. Parekh (2006) can also be another example of analysing particular cases such as Muslim headscarves. He states that religious symbols cannot be defined and compared in the abstract, both because they rarely have the same equivalent significance and because they acquire different meanings in different contexts and historical periods, and might sometimes even cease to be religious in nature. We need to contextualize them and compare them not abstractly or "in themselves", but in terms of the character and significance they might have acquired at a particular time (Parekh 2006: 251-252). Therefore, the substantial dimension of contextualism is that the normative dimension of general principles can only have meaning in a given context. We may even say that contex- 
tualism plays the role of the mediator between a general principle and its specific treatment, and it is at the core of APT (Parekh 2006: 257).

That there is some affinity between diversity and context in PT is suggested by almost all multiculturalists and its critics (Barry 2001, for instance). Levy (2007: 12-13) notes that "when theorists write about cultural rights, they typically write with a few cases in mind". This makes sense; it is hard to imagine arguing about cultural rights without referring to any "culture". Political theorists also suffer the same criticisms as qualitative researchers regarding the limits of their generalisations. This is because they also work with very few particular cases, which makes it difficult to claim that arguments are universal. However, there is no evidence that they acknowledge how particular cases limit the applicability of their arguments (Flyvbjerg 2006). There is also a debate about European multiculturalism taking place in other contexts. This discussion was probably first raised by Modood et al. (2006), followed by other edited books such as Triandafyllidou et al. (2012). In Europe, diversity and multiculturalism are mainly centred on Muslims and religion, rather than race. Discussions of multicultural accommodation, therefore, needs to address the broader question of the relationship between politics and religion. Euromulticulturalism reopens the issue of secularism (Bader 2007), which is probably a distinctive European way of conducting arguments that are related to religion.

\subsection{Concluding Remarks}

The interdisciplinary relationship between APT and QR can only be an asset for a better understanding of migratory dynamics, politics and policies. In summary, APT makes use of normative concepts and principles coming from liberal and democratic traditions (equality and freedom, for instance, but also some seminal distinctions as the public/private realm), with the purpose of interpreting processes of social and political change. In doing so, it needs to use QR for generating the empirical first-hand information inferring the basic frames, themes and patterns around a conflictive situation.

Certainly, in identifying contradictions, paradoxes and gaps between principles and reality, what makes these bridging and bonding elements between APT and QR stronger is that they produce critical knowledge that is not only social and political, but also theoretically founded and empirically grounded. It can help, for instance, to develop an evidence-based theory of security encompassing all the dimensions, including human and migrant security (Zapata-Barrero and Gabrielli 2017), as well as taking into account the views of refugees and not only the interest of States. Or, at the level of diversity management, rather than border issues, an empirically grounded analysis on how people live through social conflicts in their everyday life - such as in their neighbourhood, interacting with people from different national and cultural backgrounds. This is especially relevant for migration issues, which are always in need of more demanding objective evidence for scientific development, as well as in need of offering viable policy routes to guide social and political changes. 


\section{References}

Anfara, V. A., \& Mertz, N. T. (2015). Theoretical frameworks in qualitative research. London: Sage Publications.

Arslan, L. (2015). Islam and Laïcité in France. In M. Burchardt \& I. Michalowski (Eds.), After integration Islam, conviviality and contentious politics in Europe (pp. 187-204). Wiesbaden: Springer Fachmedien Wiesbaden.

Bader, V. (2007). Secularism or democracy? Associational governance of religious diversity. Amsterdam: Amsterdam University Press (Imiscoe Research Series).

Bader, V., \& Saharso, S. (2004). Contextualized morality and ethno-religious diversity. Ethical Theory and Moral Practice, 7(2), 107-115.

Ball, T. (1995). Reappraising political theory. Oxford: Clarendom Press.

Barry, B. (2001). Culture and equality. Cambridge: Harvard University Press.

Bauböck, R. (2008). Normative political theory and empirical research. In D. Della Porta \& M. Keating (Eds.), Approaches and methodologies in the social sciences: A pluralist perspective (pp. 40-60). Cambridge: Cambridge University Press.

Bird, K., Saalfeld, T., \& d Wüst, A. M. (Eds.). (2011). The political representation of immigrants and minorities: Voters, parties and parliaments in liberal democracies. London: Routledge.

Bloemraad, I., \& Schönwälder, K. (2013). Immigrant and ethnic minority representation in Europe: Conceptual challenges and theoretical approaches. West European Politics, 36(3), 564-579. https://doi.org/10.1080/01402382.2013.773724.

Boccagni, P. (2015). The difference diversity makes: A principle, a lens, an empirical attribute for majority-minority relations. UK: Palgrave Macmillan.

Bowen, G. A. (2008). Naturalistic inquiry and the saturation concept: A research note. Qualitative Research, 8(1), 137-152.

Cameron, D. (2011). Full transcript: David Cameron speech on radicalisation and Islamic extremism, Munich, 5 February, New Statesman. http://www.newstatesman.com/blogs/thestaggers/2011/02/terrorism-islam-ideology. Accessed Feb 2017.

Carens, J. H. (1987). Aliens and citizens: The case for open borders. The Review of Politics, 49(2), 251-273.

Carens, J. H. (1996). Realistic and idealistic approaches to the ethics of migration. The International Migration Review, 30(1), 156-170. Special Issue: Ethics, Migration, and Global Stewardship.

Carens, J. H. (2004). A contextual approach to political theory. Ethical Theory and Moral Practice, $7(2), 117-132$.

Carens, J. H. (2013). The ethics of immigration. Oxford: Oxford University Press.

Cohen, S. (1986). Knowledge and context. The Journal of Philosophy, 83(10), 574-583.

Cole, P. (2000). Philosophies of exclusion: Liberal political theory and immigration. Edinburgh: Edinburgh University Press.

Crul, M., \& Vermeulen, H. (2003). The second generation in Europe. International Migration Review, 37(4), 965-986.

Crul, M., Schneider, J., \& Lelie, F. (Eds.). (2012). The European second generation compared: Does the integration context matter? (IMISCOE Research Series) Amsterdam: Amsterdam University Press.

Dancygier, R. M. (2010). Immigration and conflict in Europe. Cambridge: Cambridge University Press.

De Rose, K. (1999). Contextualism: An explanation and defense. In J. Greco \& E. Sosa (Eds.), The Blackwell guide to epistemology. Oxford: Blackwell Publishers.

Favell, A. (1998). Applied political philosophy at the rubicon: Will Kymlica's multicultural citizenship. Ethical Theory and Moral Practice, 1(2), 255-278.

Favell, A., \& Modood, T. (2003). The philosophy of multiculturalism: The theory and practice of normative political theory. In A. Finlayson (Ed.), Contemporary political philosophy: A reader and guide (pp. 484-495). Edinburgh: Edinburgh University Press. 
Flyvbjerg, B. (2006). Five misunderstandings about case-study research. Qualitative Inquiry, $12(2), 219-245$.

Frege, G. (1884). The foundations of arithmetic. Evanston: Northwestern University Press.

Freilich, J. D., \& Guerette, R. T. (2006). Migration, culture, conflict, crime and terrorism. Aldershot: Ashgate.

Fusch, P. I., \& Ness, L. R. (2015). Are we there yet? Data saturation in qualitative research. The Qualitative Report, 20(9), 1408-1416.

Generalitat de Catalunya. (2015). Guia per al respecte a la diversitat de creences als centres educatius de Catalunya, Col-lecció "Guies sobre la Diversitat Religiosa". Barcelona: Generalitat de Catalunya. http://www.gencat.cat/governacio/pub/sum/dgar/guia_educatius.pdf. Accessed February 2017.

Gerring, J. (1999). What makes a concept good? A criterial framework for understanding concept formation in the social sciences. Polity, 31(3), 357-393.

Gibney, M. J. (2008). Who should be included? Noncitizens, conflict and the constitution of the citizenry. In F. Stewart (Ed.), Horizontal inequalities and conflict: Understanding group violence in multiethnic societies (pp. 25-40). Basingstoke: Palgrave Macmillan.

Glorius, B., \& Doomernik, J. (2016). Refugee migration and local demarcations: New insight into European localities. Journal of Refugee Studies, 29(4), 429-439. https://doi.org/10.1093/jrs/ few04.

Guest, G. (2006). How many interviews are enough? An experiment with data saturation and variability. Field Methods, 18(1), 59-82.

Guiraudon, V., \& Lahav, G. (2007). Immigration policy in Europe: The politics of control. Abingdon: Routledge.

Hampshire, J. (2013). The politics of immigration: Contradictions of the liberal state. Cambridge: Polity Press.

Hochschild, J., \& Mollenkopf, J. H. (2009). Modeling immigrant political incorporation. In J. L. Hochschild \& J. H. Mollenkopf (Eds.), Bringing outsiders in. Transatlantic perspectives on immigrant political incorporation (pp. 15-30). Ithaca: Cornell University Press.

Hollifield, J. (1992). Immigrants, markets, and states: The political economy of postwar Europe. Harvard: Harvard University Press.

Hsieh, N. (2016). Incommensurable values. In E. N. Zalta (Ed.), The Stanford encyclopaedia of philosophy (Spring). http://plato.stanford.edu/archives/spr2016/entries/value-incommensurable/. Accessed Feb 2017.

Hsieh, H. F., \& Shannon, S. E. (2005). Three approaches to qualitative content analysis. Qualitative Health Research, 15(9), 1277-1288.

Jabareen, Y. (2009). Building a conceptual framework: Philosophy, definitions, and procedure. International Journal of Qualitative Methods, 8(4), 49-62.

Jehn, K. A., Greer, L. L., \& Ruper, J. (2008). Diversity, conflict, and their consequences. In A. P. Brief (Ed.), Diversity at work (pp. 127-174). Cambridge: Cambridge University Press.

Kastoryano, R. (Ed.). (2009). An identity for Europe: The relevance of multiculturalism in EU construction. US: Palgrave Macmillan.

Kukathas, C. (2004). Contextualism reconsidered: Some sceptical reflections. Ethical Theory and Moral Practice, 7(4), 215-225.

Kymlicka, W. (2015). Solidarity in diverse societies. Comparative Migration Studies, 3, 17. https:// doi.org/10.1186/s40878-015-0017-4.

Lægaard, S. (2014). Multiculturalism and contextualism: How is context relevant for political theory? European Journal of Political Theory, 14(3), 259-276. https://doi. org/10.1177/1474885114562975.

Lægaard, S. (2016). Contextualism in normative political theory. In W. R. Thompson (Ed.), Oxford research encyclopaedia of politics. Oxford: Oxford University Press.

Levy, J. T. (2007). Contextualism, constitutionalism, and modus vivendi approaches. In A. Laden \& D. Owen (Eds.), Multiculturalism and political theory (pp. 173-197). Cambridge: Cambridge University Press. 
Lindkilde, L. E., Mouritsen, P., \& Zapata-Barrero, R. (2009). The Muhammad Cartoons controversy in comparative perspective. Special Issue of Ethnicities, 9(3), 291-313.

List, C., \& Valentini, L. (2016). The methodology of political theory. In H. Cappelen, T. S. Gendler, \& J. Hawthorne (Eds.), The Oxford handbook of philosophical methodology (pp. 525-254). Oxford: Oxford University Press.

Margolis, E., \& Laurence, S. (2014). Concepts. In E. N. Zalta (Ed.), The Stanford encyclopaedia of philosophy (Spring). https://plato.stanford.edu/archives/spr2014/entries/concepts/. Accessed Feb 2017.

Martiniello, M. (2005). Political participation, mobilisation and representation of immigrants and their offspring in Europe. Willy Brandt Series of Working Papers in International Migration and Ethnic Relations, School of International Migration and Ethnic Relations, Malmö University.

Meer, N., Modood, T., \& Zapata-Barrero, R. (Eds.). (2016). Interculturalism and multiculturalism: Debating the dividing lines. Edinburgh: Edinburgh University Press.

Miles, M., \& Huberman, A. M. (1994). Qualitative data analysis. Thousand Oaks: Sage Publications.

Miller, D. (2013). Justice for earthlings essays in political philosophy. Cambridge: Cambridge University Press.

Modood, T., Triandaffyllidou, A., \& Zapata, R. (Eds.). (2006). Multiculturalism, Muslims and citizenship: A European approach. London: Routledge.

Myers, M. D. (2008). Qualitative research in business \& management. London: SAGE Publications.

Oberschall, A. (1978). Theories of social conflict. Annual Review of Sociology, 4(1), 291-315.

Oberschall, A. (2010). Conflict theory. In K. T. Leicht \& J. C. Jenkins (Eds.), Handbook of politics: State and society in global perspective (pp. 177-193). New York: Springer.

Parekh, B. (2006). Rethinking multiculturalism: Cultural diversity and political theory. London: Palgrave.

Penninx, R., \& Roosblad, J. (Eds.). (2000). Trade unions, immigration, and immigrants in Europe, 1960-1993: A comparative study of the attitudes and actions of trade unions in seven west European countries. New York: Berghahn Books.

Pettit, P. (1991). Political theory: An overview. In P. Pettit (Ed.), Contemporary political theory (pp. 1-16). NY: Macmillan.

Picasso, P. (1966). “Truth”. In Picasso says (Trans. 1969). London: Allen \& Unwin.

Portes, A. (2008). Migration and social change: Some conceptual reflections. The Center for Migration and Development, Working Paper Series 08-04, Princeton University. https://www. princeton.edu/cmd/working-papers/papers/wp0804.pdf. Accessed Feb 2017.

Rawls, J. (1999). A theory of justice (Rev. ed.). Cambridge, MA: Harvard University Press.

Ritchie, J., \& Lewis, J. (Eds.). (2003). Qualitative research practice: A guide for social science students and researchers. Thousand Oaks: Sage Publications.

Rysiew, P. (2016). Epistemic contextualism. In E. N. Zalta (Ed.), The Stanford encyclopaedia of philosophy (Spring). http://plato.stanford.edu/archives/sum2016/entries/contextualism-epistemology/. Accessed Feb 2017.

Saunders, M. N. K., Gray, D. E., Tosey, P., \& Sadler, S. E. (2015). Concepts and theory building. In L. Anderson, J. Gold, J. Stewart, \& R. Thorpe (Eds.), A guide to professional doctorates in business and management (pp. 35-56). London: Sage Publications.

Schwandt, T. A. (2007). Contextualism. In T. A. Schwandt (Ed.), The SAGE dictionary of qualitative inquiry (p. 43). London: Sage Publications.

Schwartz-Shea, P., \& Yanow, D. (2012). Interpretive research design: Concepts and processes. New York: Routledge.

Sigona, N. (2014). The politics of refugee voices: Memories, narratives and representations of forced migration. In E. Fiddian-Qasmiyeh, G. Loescher, K. Long, \& N. Sigona (Eds.), The Oxford handbook on refugee and forced migration studies. Oxford: Oxford University Press.

Simmel, G. (1903). The sociology of conflict: I. American Journal of Sociology, 9(1903), 490-525. Slim, B., \& Squires, J. (Eds.). (2008). Contesting citizenship. London: Routledge.

Smits, K. (2009). Applying political theory: Issues and debates. Basingstoke: Palgrave MacMillan. 
Spencer, S. (Ed.). (2003). The politics of migration: Managing opportunity, conflict and change. Malden: Wiley-Blackwell.

Triandafyllidou, A., \& Gropas, R. (2015). What is Europe. London: Palgrave.

Triandafyllidou, A., Modood, T., \& Meer, N. (2012). European multiculturalisms: Cultural, religious and ethnic challenges. Edinburgh: Edinburgh University Press.

Vertovec, S. (Ed.). (2015). Routledge international handbook of diversity studies. Abingdon: Routledge.

Weldom, T. D. (1953). The vocabulary of politics. Baltimore: Penguin Books.

White, S. (2002). Introduction: Pluralism, platitudes, and paradoxes: Fifty years of western political thought. Political Theory, 30(4), 472-481.

Yanow, D., \& Schwartz-Shea, P. (Eds.). (2006). Interpretation and method: Empirical research methods and the interpretive turn. New York: M. E. Sharpe.

Yanow, D., \& Schwartz-Shea, P. (2009). Interpretive research: Characteristics and criteria. Revue internationale de psychosociologie, 35(XV), 29-38. https://doi.org/10.3917/rips.035.0029.

Zapata-Barrero, R. (2004). Political theory today: Political innovation and the management of structural change. European Political Science, 3(3), 39-50.

Zapata-Barrero, R. (Ed.). (2015). Interculturalism in cities: Concept, policy and implementation. Cheltenham: Edward-Elgar Publishing.

Zapata-Barrero, R., \& Díez-Nicolas, J. (2012). Islamophobia in Spain? Political rhetoric rather than a social fact. In M. Helbling (Ed.), Islamophobia in Western Europe and North America (pp. 83-97). London: Routledge, Taylor and Francis.

Zapata-Barrero, R., \& Gabrielli, L. (2017). Ethics and the securitization of migration. In P. Bourbeau (Ed.), Handbook on migration and security (pp. 125-143). Cheltenham: Edward Elgar.

Zapata-Barrero, R., Caponio, T., \& Scholten, P. (Eds.). (2017a). Symposium on theorizing 'the local turn' in the governance of immigrant policies: A multi-level approach. International Review of Administrative Sciences (IRAS), 83(2), June 2017.

Zapata-Barrero, R., Dahnke, I., \& Markand, L. (Eds.). (2017b). Immigrant incorporation in political parties: Exploring the diversity gap. Ethnic and Racial Studies, 40(5), 751-765.

Open Access This chapter is licensed under the terms of the Creative Commons Attribution 4.0 International License (http://creativecommons.org/licenses/by/4.0/), which permits use, sharing, adaptation, distribution and reproduction in any medium or format, as long as you give appropriate credit to the original author(s) and the source, provide a link to the Creative Commons license and indicate if changes were made.

The images or other third party material in this chapter are included in the chapter's Creative Commons license, unless indicated otherwise in a credit line to the material. If material is not included in the chapter's Creative Commons license and your intended use is not permitted by statutory regulation or exceeds the permitted use, you will need to obtain permission directly from the copyright holder.

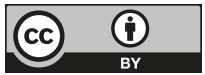

